\title{
CATHERINE KINGFisher
}

Department of Anthropology

University of Lethbridge

Lethbridge, Alberta T1K 3M4

Canada

\section{MiChaEL GOLDSMITH}

Anthropology Programme.

University of Waikato

Hamilton

New Zealand

\section{Reforming Women in the United States and Aotearoa/New Zealand: A Comparative Ethnography of Welfare Reform in Global Context}

\begin{abstract}
Historically, the United States and Aotearoa/New Zealand symbolize opposite poles of an individualist-collectivist welfare state continuum. Until recently, Aotearoa/New Zealand was known as a "cradle-to-grave" welfare state, with "universal" employment and coverage in health and education. U.S. history, in contrast, is marked by an unabashed individualism and a residualist approach to welfare. Recent neoliberal reforms, however, have engendered a convergence between the two countries in the conceptualization and organization of assistance for poor single mothers. Most notable are the "workfare" provisions of legislative changes made in 1996 in the two countries, which work to reconstitute poor mothers as potential able-bodied workers. In this article we analyze welfare reform in the United States and Aotearoa/New Zealand, with particular reference to how poor single mothers respond to, comply and cope with, or resist neoliberal strategies. Analysis is based on participant-observation, interviews, and focus groups conducted between 1989 and 1999. [welfare reform, neoliberalism, globalization, gender, the United States, Aotearoa/New Zealand]
\end{abstract}

[Welfare] programs ... degrade and enslave millions. They have made generations of Americans nothing more than animals in the Government barn. [U.S. Representative Funderburk, in U.S. Government 1995]

At a certain point an overly generous welfare system will make it more worthwhile for whole categories of people to rely on the State rather than their own initiative. [National Party of New Zealand 1993:15]

$\mathbf{T}$ These two quotes are emblematic of the discourse of welfare reform in the United States and New Zealand, ${ }^{1}$ and they are also representative of discourses being produced in other Western welfare states with regard to the restructuring of social provisioning. The point being made, in both cases, is that welfare as we have known it has promoted parasitic behavior, thereby discouraging development of the capacities requisite to proper personhood and citizenship, namely, independence, autonomy, and self-sufficiency. The purported solution to the evil of "trapping people at their lowest and least" (U.S. Senator Ashcroft, in U.S. Government 1996) is "reform," entailing liberation from welfare.
This new/recycled approach to poverty and provisioning marks the consolidation of a shift from Keynesian to neoliberal forms of governance. The shift entails a particular double bind for poor single mothers. It is well known that women have higher poverty rates than men because they suffer various forms of discrimination in the workplace and are more likely to have sole custody of dependent children (Starrels et al. 1994). The shift to neoliberal governance serves to heighten this vulnerability, insofar as it represents a shift from the constitution of women as mothers and housewives to their constitution as potential ablebodied workers. ${ }^{2}$ In this new regime, motherhood is no longer regarded as a legitimate reason for poor women's reliance on the state; accordingly, poor mothers on welfare have become the targets of welfare reform measures. ${ }^{3}$

In some respects, the U.S. and New Zealand govemments have recently adopted similar positions in their conceptualizations and organizations of financial assistance for poor single mothers. In essence, both countries have worked toward tightening eligibility requirements and institutionalizing workfare. In the process of these reforms, the programs traditionally targeting poor single mothers- 
Aid to Families with Dependent Children (AFDC) in the United States and the Domestic Purposes Benefit (DPB) in New Zealand-have been transformed to reflect and encourage new subjectivities on the part of their beneficiaries. This apparent convergence, with particular reference to the reconstitution of gendered subjectivity, is the focus of our analysis here. Our concern is threefold. First, we are interested in both similarities and differences between New Zealand and the United States at the discursive/programmatic level of policy and popular debate. Second, we are interested in the experiences of the targets of the reforms. How do poor single mothers in these two contexts discursively interpret, respond to, comply and cope with, or resist neoliberal strategies? How are they struggling to constitute their own subjectivities? Finally, we are interested in the relationship between poor single mothers' and comparativist scholars' readings of the political/social terrain. How do theoretical models of globalization intertwine with everyday experiences? The relationship between the two is messy and even contradictory; not only is the trajectory of globalization itself multilinear, but the trajectory of individual lives caught up in globalizing processes may be surprisingly varied.

We begin with a discussion of the global context of welfare reform and of the rise of neoliberalism as a cultural system. We then sketch an overall historical and conceptual characterization of welfare programs in New Zealand and the United States, with particular reference to those measures directed at poor single mothers both before and after the implementation of neoliberal reforms. We proceed to focus on how these recent reforms have attempted in both countries to constitute poor single mothers as generic workers, looking briefly at policies and in some detail at the way women on welfare talk about the practices to which they have been subjected. While all our respondents report significant changes in those practices, most of which have threatened to reduce their income, autonomy, and self-esteem, their response to the changes is not one of total despair or apathy. This prompts our concluding plea for sensitivity to ethnographic and historical particularities in the study of globalization, as against notions of its unidirectional inevitability.

\section{The Global Context of Welfare State Reform}

Welfare reform does not just take place in nation-states in isolation but in the larger context of nation-states' relationships with each other and with other transnational nonstate actors or forces (e.g., multinationals; international organizations such as the World Bank, the International Monetary Fund, the International Labor Organization, and the World Trade Organization; and international trade agreements, such as the North American Free Trade Agreement [NAFTA]). Welfare reform measures under- taken in particular nation-states must therefore be situated in the context of a global political and cultural economy.

Globalization, characterized as the increasing internationalization of economic and social phenomena, refers to two interlinked processes: on the one hand, economic globalization, or the "rapid growth of transactions and institutions that are outside the older frameworks of inter-state relations" (Sassen 1996a:9); and, on the other hand, the globalization of culture, which refers to the increasing mobility of people, ideas, and practices. Both processes indicate that the sovereignty of the nation-state, in terms of its ability to control what goes on materially and ideologically within its territory, is not what it used to be and is in the process of transformation-although no one is quite clear as to the results of this transformation.

Both the United States and New Zealand have experienced changes in recent decades reflective of their changing sovereignty in a global political-cultural economy. Susser (1997:396) accordingly situates the 1996 U.S. Personal Responsibility and Work Opportunity Reconciliation Act (PRWORA) in the context of a worldwide "expansion of the industrial labor force" that targets women and is accompanied by a shift in gender expectations. What we now find in the United States, she claims, is "an informational economy, accompanied by enfeebled unions, less security for most workers, a growing informal labor force, the shrinking of the welfare state and increasing inequality" (1997).

Several factors have also altered New Zealand's political and economic relations with the "outside world" and made it more open to external influences of the sort that globalization theory highlights. First, with Britain's entry into and growing commitment to the European Union, access to the major market for the sorts of commodities that New Zealand traditionally produced (meat, wool, and dairy products) could no longer be taken for granted. Second, the Australian and New Zealand labor and commodity markets became much more integrated through the creation of an arrangement known as the Closer Economic Relationship (CER), thus exposing New Zealand to its much larger neighbor. Third, the rise of the East Asian "tiger" economies opened up new markets for new and traditional export products. Finally, and partly as a response to these developments, New Zealand's own trade barriers have been progressively dismantled, its economic and financial sectors have been deregulated, and many state assets have been sold to local and (especially) international interests (Jesson 1987; see also Easton 1997, 1999; Kelsey 1993, 1997, 1999). ${ }^{4}$

Thus, while we "should not exaggerate the degree to which global forces overdetermine the fate of national welfare states" (Esping-Andersen 1996:5), it is clear that "global competition does narrow the field of domestic policy choice" (Esping-Andersen 1996:2). In addition, the 
"challenges" to the welfare state identified by EspingAndersen-changing economic conditions and demographic trends and a disjuncture between the current social order and that for which the welfare state was designed (Esping-Andersen 1996:6-9)—must themselves be situated in a global context. The changing economic conditions to which Esping-Andersen refers clearly occur in reference to the changes in the international division of labor noted by Susser (1997). In addition, shifts away from an ideal homogeneous population composed of similar nuclearfamily units reflect, at least in part, increasing tolerance for heterogeneity and difference in household arrangements. Paradoxically, this internal/domestic differentiation may coexist with what is also deemed to be the inherent homogenization of globalism.

\section{Neoliberalism}

A key feature of both economic and cultural globalization is the global spread of specifically neoliberal forms of governance (e.g., Gill 1995; Teeple 1995), characterized by an international and patterned shift in the direction of increasing marketization, a redrawing of the public/private distinction, valorization of possessive individualism, and decreasing state expenditure (but sometimes, paradoxically, with increasing state interference) in social arenas. Most notable in the case of welfare state restructuring in countries like the United States and New Zealand is "a strategy of deregulating wages and the labour market, combined with a certain degree of welfare state erosion" (Esping-Andersen 1996:10).

Neoliberalism is perhaps best conceived of as a cultural system that makes certain claims about the economy, the proper role of the state, and the nature of personhood that in turn serve to organize society in highly gendered ways. ${ }^{5}$ Most significantly for our purposes here, neoliberal culture depends on a theory of economic individualism (Lukes 1973). This entails a particular conceptualization of personhood, on the basis of which a unique vision of society is constructed, namely, one with a minimalist state whose role is simply to enable the free exchange of goods and services between rational, independent individuals. As Marcel Mauss pointed out in 1938, however, this philosophy of individualism is both culturally specific-Westernand of relatively recent historical origin (see [1938]1985). It is in this regard that La Fontaine makes a case for "recognition that concepts of the person are embedded in a social context" and are related to "a particular concept of society as a whole" (1985:138, 137).

The general distinction anthropologists tend to make between the West and "the rest" with regard to ideas of personhood is between individualistic and sociocentric, or "holistic," conceptions of personhood (Dumont 1980; Morris 1994; see also Carrithers et al. 1985). Although simplistic (Morris 1994), as a gross distinction it may perhaps be useful. Geertz writes in this regard that

the Western conception of the person as a bounded, unique, more or less integrated motivational and cognitive universe, a dynamic center of awareness, emotion, judgment, and action organized into a distinctive whole and set contrastively both against other such wholes and against a social and natural background is, however incorrigible it might seem to us, a rather peculiar idea within the context of the world's cultures. [1975:48]

Neoliberalism, however, implicitly challenges the view that personhood is socially and culturally constructed by asserting that the autonomous and rational monad of Western thought is natural and that any other versions of personhood are more ideological than cultural (Fairclough 1991; Rose 1989).

In addition, and as Western feminists have repeatedly argued, the "individual" of liberal theory is not a generic individual but a specifically male (and Anglo) individual whose independent individuality is predicated on women's dependence and subservience (Brown 1995; Pateman $1988,1989)$. The latter is partially manifested in women's circumscribed relationship to paid labor, which is constrained by their "private" duties and is constructed as secondary in importance to both their private responsibilities and their men's public functioning. Women's resulting status as secondary citizens and wage earners has had implications, in turn, for their relationship to the state. Whereas men in Western welfare states have made claims against the state on the basis of their identities as public, rights-bearing citizens, women's claims against the state have usually been made on the basis of their identities as private persons and dependent "clients" (Fraser 1989; Pateman 1989).

At one level, neoliberalism overcomes the myriad problems associated with welfare states' characterization of women as "dependents" and as recipients of "charity." In its overvaluation of the "individual," neoliberalism works to erase all negative and "undeserving" forms of dependency, and, by pushing liberal feminism to its reductio ad absurdum, invites women as well as men to participate in this erasure. Thus "the 'sanctity of motherhood' no longer shields women from the market; rather, a new vision of a 'gender-neutral worker-citizen' has emerged in proposals to transform social assistance" (Scott 1996:8; see also Brodie 1996; Shaver 1995). In addition, in the context of economic globalization, such as that represented by NAFTA and Closer Economic Relationship (CER), economic citizenship, as a social right to economic well-being and survival, is no longer the sole property of individuals but one of firms and markets - of what Sassen refers to as "global economic actors" (1996b:38). Nevertheless, women are being reconstituted as economic agents-as independent, autonomous, rational decision makers and utility 
maximizers. That which falls outside of this realm - and into the realm of reproduction and unpaid labor-is erased. This erasure is purely nominal, however, with the consequence that women are forced to continue in their "private" responsibilities while simultaneously shouldering the burdens of restructuring as they struggle to fill in the gaps left by a retreating state. The reality of such women's "ablebodiedness" is thus questionable.

\section{History of Welfare Programs}

Historically, the New Zealand and U.S. welfare states have been situated at opposite ends of an individualist-collectivist continuum. From the 1890 s to the 1980 s, most New Zealanders and their governments espoused an ideology of collectivism, in which the state was responsible for the basic needs of its members. Indeed, New Zealand was touted as a "cradle-to-grave" welfare state with "universal" employment and "universal" coverage in areas such as health and education. In contrast, U.S. history is marked by an unabashed individualism, with the state taking a residualist approach to welfare in most areas. Therefore, despite the fact that in both cases it was the Great Depression of the 1930s that precipitated the development of Social Security Acts (in 1935 in the United States and 1938 in New Zealand), the acts themselves were different in three crucial respects. First, in the United States, restrictive legislation rewarded higher earnings and protected "only a minority of the population against only a few risks," while the New Zealand act, according to some historians, "covered everybody against every risk, and redistributed income downward" (Richards 1994:vii-viii). Second, whereas New Zealand built its welfare state on a foundation of full employment and the family wage, full employment never featured in the organization of the U.S. welfare state. Finally, while the United States has drawn on both "contributory" and "noncontributory" funding, New Zealand has tended to fund its programs from general revenues.

These fundamental differences in the underpinnings and organization of welfare states are reflected in various typologies of welfare states. Thus the United States can be characterized as a minimalist or needs-based regime, while New Zealand could be characterized, until recently, as closer to the other end of the spectrum: the social citizenship/rights-based or institutional regime, in which people are entitled to social services by virtue of being citizens and in which assistance is designed to support participation in society rather than just survival (Mishra 1977). In Esping-Andersen's (1990) typology, the United States is a liberal welfare state characterized by heavy means testing, residual benefits, and private insurance, while New Zealand was social-democratic, characterized by universal benefits and a commitment to full employment. As Sainsbury (1996) points out, however, such ideal types fail to capture the nuances of individual regimes and are thus misleading. The United States, for instance, has both residual and institutional characteristics, as evidenced by its two-tier system of social insurance on the one hand and welfare on the other. New Zealand is similarly mixed, in that a certain degree of means testing has always existed alongside universal programs. Any particular categorization of welfare state regimes must also recognize historical fluctuations.

In addition, Sainsbury continues, welfare state typologies are often of limited use in relation to the experiences of different segments of the population within particular welfare regimes. This is clearly the case in the United States and New Zealand with regard to poor single mothers. Specifically, when gender and race are included in the analysis, the United States and New Zealand no longer appear at opposite ends of a residualist, rights-based continuum but, rather, seem to have approached poor single mothers in remarkably similar ways. First, given New Zealand's emphasis on full employment as the foundation of its welfare state (resulting in its characterization as a "wage-earners" welfare state [Castles 1996]), those who were outside the labor force never fared as well. Thus the New Zealand Social Security Act did not, in fact, cover "everybody against every risk" (Richards 1994:viii) but excluded many women and Maori. The "everybody" covered was European and male. In this context, "undeserving," morally suspect women-non-Europeans, nonwidows-had difficulty gaining state support. In fact, no specific provisions were made for unmarried mothers until 1973 (Beaglehole 1993). Prior to this, such women had to get either an "emergency benefit" or be placed on a widow's or deserted wife's benefit, despite the fact that they were neither; in other words, they had to be transferred from an "undeserving" to a "deserving" category of poor (although deserted wives were never as "deserving" as widows and often had difficulty gaining access to support). Thus, in New Zealand, "the plight of single mothers before the introduction of the Domestic Purposes Benefit (DPB) was characterised by poverty, dependence and powerlessness" (Beaglehole 1993:30). A similar pattern existed in the United States, where, prior to the 1935 Social Security Act, the only program available to single mothers was Mothers' Pensions, which supported white widows to the exclusion of most other women (see Kingfisher 1999).

\section{Prereform Welfare Programs in New Zealand and the United States}

The main program for poor single mothers in New Zealand has been the Domestic Purposes Benefit, which, as its name implies, was designed to support single parents (usually mothers) in their roles as caretakers for dependent children. The DPB was introduced in 1973, in the midst of furious debate concerning women's sexuality. This late introduction stems from an ambivalence in New Zealand 
culture concerning single mothers. Once introduced, however, the DPB was relatively generous, providing single mothers with the option of staying out of the workforce until their youngest child was 18 . Until the reforms of the early 1990s, the DPB was more or less stable, reflecting a general comfort with a gendered division of labor in which women's primary role was that of mother (although mothers on the DPB were generally deemed less respectable than their married counterparts).

The comparable program in the United States has been AFDC (Aid to Families with Dependent Children). Following Mothers' Pensions, which were instituted in a number of states beginning in 1911, AFDC was enacted in 1935 with the passage of the Social Security Act. Originally known as Aid to Dependent Children, or ADC, indicating that provisions were being directed to children rather than mothers (although mothers were conduits for provisioning), coverage for mothers was introduced in 1950 , and coverage for unemployed parents was introduced in 1961. Finally, in 1962 ADC was renamed AFDC to reflect a targeting of families rather than of individual children. ${ }^{6}$

Both AFDC and the DPB were intended to cover poor families' basic needs, including shelter, utilities, and personal needs. In New Zealand the DPB also covers food expenses, while in the U.S. food expenses have been met by Food Stamps, a separate program providing food coupons on a monthly basis. Finally, in New Zealand, health care has been provided by an ostensibly universal system of health care provision, with the poor having access to the same system as the rest of the population; while in the United States, health care for some of the poor has been provided through the Medicaid program.

Although instituted at different times, and articulating differently with the welfare states of which they are a part,? AFDC and the DPB have served the same population of mostly women single parents and their children and have shared a history of similar treatment of that population. Two features of this treatment are notable. The first is the surveillance of women to ensure either that they had no male partners or, if they did, that the women were promptly removed from the welfare rolls. In the United States, this was accomplished by means of "man in the house" rules, which gave welfare workers the right to visit recipients' homes, often unannounced and at odd times, in order to check for evidence of adult male presence. Similar practices existed in New Zealand. A second similarity in the two programs is that benefits have been discontinued once children have reached adulthood, providing poor women with aid in their capacities as mothers rather than by virtue of their poverty.

Surveillance and the conditionality of benefits indicate that AFDC and the DPB assumed and reinforced a construction of women as mothers. If not in the service of husbands, they could be in the service of the state. But they could not be in the service of both simultaneously. And once this service was discontinued-once they were no longer engaged in the rearing of children-their benefits were discontinued as well.

\section{The Reforms}

AFDC and the DPB also had their positive side, however. Both programs took the first step toward allowing women to be treated as economically independent persons, thus giving them the means to leave abusive relationships or, in the case of never-partnered women in New Zealand, to keep their children, as opposed to having to adopt them out (Beaglehole 1993). In one sense, the new reforms pervert this by demanding "independence" through the transformation of poor bodies into work-ready labor units.

In addition to the general historical similarities outlined above, there are remarkable parallels in the nature of the reforms currently being proposed and instituted in the realm of policy provisions for poor single mothers in New Zealand and the United States, ${ }^{8}$ the most notable being "workfare" provisions that endeavor to reconstitute poor mothers as able-bodied workers." The programmatic similarities between the two countries are discursively mirrored in official and popular arguments for benefit cuts and workfare, which have been made on the basis of the mutually supporting claims that "we" (the taxpayers) can no longer afford to support the poor and that welfare "disempowers" recipients, who are thereby rendered lazy, dependent, and irresponsible. In both contexts, the resulting benefit cuts and work tests have been referred to as "tough love," the end result of which will be "empowered," "responsible," "independent," "contributing" members of society (Kingfisher 1999).

The trend in the United States in the past 20 yearsmanifested in the 1981 Omnibus Budget Reconciliation Act (OBRA), ${ }^{10}$ the 1988 Family Support Act, ${ }^{11}$ and the 1996 Personal Responsibility and Work Opportunity Reconciliation Act (PRWORA) ${ }^{12}$-is one of decreasing federal control (which can be important in terms of rights and benefit levels) and increased institutionalization of workfare. Significantly, these shifts are occurring in the face of a decreasing value of the benefit and in a context in which minimum-wage jobs fail to provide for basic subsistence. ${ }^{13}$

Though New Zealand is clearly following the United States in terms of benefit cuts and workfare, the latter is not quite the same as workfare in the United States. While the 1996 U.S. welfare reform bill requires recipients to engage in work-related activity after they have been on assistance for two years, the 1997 changes in the New Zealand welfare system only require that mothers seek part-time employment once their youngest child reaches the age of 14 . This difference may reflect the relatively greater recognition of mothering as "work" in the New Zealand context. Thus, while New Zealand is keeping up with the United 
States in terms of promoting the idea of workfare, it is far behind in its institutionalization. ${ }^{14}$

There have been two recent phases of welfare reform in New Zealand relevant to our discussion here (Stephens 1999). First, in spring 1991, the newly elected National government instituted a number of changes in the welfare state that reflected a shift from universal to targeted provisioning (Boston et al. 1999), underpinned by an individualist rather than collectivist approach, and employed an absolute rather than relative definition of poverty (Waldegrave and Frater 1996). ${ }^{15}$ The second phase of reform in New Zealand began with the 1996 Tax Reduction and Social Policy Bill. This involved two changes to the DPB, effective April 1, 1997. First, recipients whose youngest child was between the ages of 7 and 13 were now required to attend a yearly interview with Income Support Services that would "signal to beneficiaries that they should be taking steps to move towards independence and employment and provide appropriate advice to help them do this" (New Zealand Finance and Expenditure Committee 1996:viii); and second, recipients whose youngest child was 14 years of age or more would be subjected to a work test, including the requirement that they be in training, seeking paid employment, or in paid employment for 15 hours per week. The penalties for failing to fulfill these requirements take the form of benefit reductions. ${ }^{16}$ In addition to these legislative changes, in 1998 New Zealand Income Support and Employment New Zealand merged to form Work and Income New Zealand (WINZ). Two years later WINZ's dismal public reputation, stemming from accusations of extravagance and a private sector corporate ethos, led to another name change-Department of Work and Incomebut, crucially, the relabeling exercise did not separate the two key nouns.

\section{From (Gendered) Mother to (Generic) Worker}

Arguments in favor of welfare reform rest on particular constructions of personhood and citizenship, the ascendancy of which signal a shift in the relationship between poor women and state provision. If feminism has struggled with the contradictions between the welfare state's construction of women as mothers and dependents (and thus as secondary citizens) and its contribution to women's independence from abusive relationships with men, neoliberalism has responded to these struggles and critiques by "degendering" individuals' relationships to state provision. Now women, too, can be counted as separate, autonomous "individuals" whose very individuality provides them with the means to achieve self-sufficiency.

Poor mothers, however, fail to fulfill the requirements of full individuality and autonomy and, thus, of citizenship. But this "failure" is not constituted as one of a particular political or economic system; nor is it seen to be a feature of a gender regime that produces male citizens and incom- plete dependent women. Rather, the failure is attributed to women themselves, who are always already incomplete and dependent. The result is that poverty policy is directed at the reformation of individuals rather than structures: thus the rhetoric of empowerment, motivation, and "tough love." As federal programs are devolved to states, "welfare dependency" is devolved to individuals and pathologized. Thus, the disadvantaged, the marginalized, "are to be assisted not through the ministrations of solicitous experts proffering support and benefit cheques, but through their engagement in a whole array of programmes for their ethical reconstruction as active citizens" (Rose 1996:59-60; see also Kingfisher 2001).

Insofar as poverty is constituted as a reflection of an individual, feminized, and racialized incapacity, the responses of the neoliberal state are channeled in two specific directions, which we can refer to as residualist (Sainsbury 1996) and incentivist. The first is the route of outright cuts, including benefit reductions and limitations, restrictions on eligibility, and increased targeting and means testing. This route is particularly attractive if the existence of the poor is constituted as reflective of an individualized incapacity that is perhaps not only inherent but specifically enhanced by welfare programs that have encouraged dependency and parasitic behavior. In other words, if freedom requires the absence (or at least the minimization) of interference-what is known in liberal theory as negative liberty (Ramsay 1997) - then welfare provisions undermine recipients' liberty, as well as the liberty of taxpayers who are forced to contribute to welfare programs.

The incentivist route to reform draws on a more positive version of freedom in recognizing that freedom requires the resources necessary to pursue one's own individual ends (Ramsay 1997). In this case, the state is seen as responsible for providing some of these resources. But the resources it provides must be of a very particular nature if the result is not to be a disabling, disempowering interference. Specifically, the resources provided must be designed so as to enhance the individual's abilities to exercise freedom, that is, autonomy, self-sufficiency, and independence. So-called incentive programs, which are highly interventionist, punitive, and in many respects illiberal, result from this position. Sanctions for children's nonattendance at school and for out-of-wedlock births and lifetime limits on the receipt of benefits (in the U.S. case) are constituted as appropriate "incentives" in this framework. Again, however, most notable in this context is workfare. "Work," as Foucault (1979:242) quotes Faucher (1838), is "the providence of the modern peoples; it replaces morality, fills the gaps left by beliefs and is regarded as the principle of all good." Workfare, in this regard, functions "as a means of promoting the personal capacities required for the exercise of autonomy" (Hindess 1997:25), positively 
contributing to poor people's "ethical reconstruction as active citizens" (Rose 1996:60)."

With the help of the disciplinary measures of cuts and so-called incentives, poor single mothers are being reconstituted as potential able-bodied workers while their former identities as mothers and dependent housewives (Mies 1986) take on increasingly negative salience. The move is one from dependence to enterprise, the latter characterized by a valorization not only of "autonomy, responsibility, initiative, self-reliance, [and] independence" but also of "a willingness to take risks, see opportunities, and take responsibility for one's own actions" (Cannan 1995:162). With their reconstitution as enterprising subjects, poor women are being compelled to enter the public realm to an even greater extent than previously (since many already combine welfare with low-wage labor, if not under-the-table work). Despite this increasing material and discursive movement of women into the public realm, however, women do not enter it as equal citizens, as the dearth of effective equality legislation indicates (Sainsbury 1996). Simultaneously, moreover, privatization of state welfare provisions is contributing to an expansion of the realm of private welfare, for which women continue to be held responsible.

The end results of the reforms have thus been a mixture of the intended and the unintended, the logical and the perverse. They are designed to reconstitute (poor) women as potential able-bodied workers and in this they appear to be succeeding, though not without some resistance on the part of poor women and their political allies. They are probably not intentionally designed to erase (unpaid) child care, but because that is not treated as "work" in policy settings, they are placing such labor under huge pressure. Finally, while they are not explicitly designed to devalue (poor) women's roles as mothers-because any policy that overtly demeans motherhood carries political risks - they do so in practice.

\section{Ethnographic Dimensions of Welfare Reform}

As Appadurai states, "If the genealogy of cultural forms is about their circulation across regions, the history of these forms is about their ongoing domestication into local practice" (1996:17). Relatedly, Sassen (1996a, 1996b) problematizes global-local/national dualisms that assume that one ends where the other begins. Instead, she asserts, we need to recognize that all global processes are territorially situated-in other words, that the global is always, and only, manifested in local specificities.

These insights generate a number of questions with regard to gender, poverty, and welfare reform, which we address here in relation to the experiences of poor single mothers. ${ }^{18}$ For instance, what shape does neoliberal reform take in welfare states with a history of universal provisions versus those characterized as minimalist or residualist? Do the discursive similarities among sites-the ubiquity of the rhetoric of independence, responsibility, motivation, selfdiscipline, and, of course, "tough love"-signal precise similarities in reform policy as it is instantiated? Or are "independence" and "tough love" refracted through different local lenses, resulting in a proliferation of family resemblances rather than exact replicas-or possibly in radically divergent practices? We need to be careful, in other words, "not to confuse similarity with convergence" (Cox 1998: 13).

\section{Methods}

This article is based on several different research strands conducted over a number of years, both formal and informal. Over the last 10 to 15 years, both authors have compiled large amounts of documentary and historical data on changing welfare regimes in the United States and New Zealand, data that serve to contextualize the ethnographic research presented here. In the United States, Kingfisher conducted an ethnographic study of women welfare workers and recipients in Michigan in 1989 and 1990 (Kingfisher 1996a, 1996b, 1998, 2001). The recipient data included in this article are drawn from her work with members of two welfare rights group, the Madrid Welfare Rights Organization (MWRO) and Low Income People for Equality (LIFE). ${ }^{19}$ In both cases, emphasis was placed on the collection of naturally occurring talk, which was then subjected to content and conversation analysis; individual interviews with core welfare rights group members were also conducted. Previously unreported material from that project is included in this article.

It is worth pointing out that the 1996 U.S. act, which serves as one focus of this article, was the culmination of trends put into place by OBRA in 1981 and the Family Support Act in 1988; thus efforts to reconstitute women's subjectivity were well under way during the time of Kingfisher's 1989-90 study. In specific relation to this (re)constitution, what has happened since then represents an intensification rather than an entirely new direction.

Our analysis of the situation of poor single mothers in New Zealand draws from both individual and team research that combined interviewing, the analysis of policy documents and media coverage, and intermittent ethnographic research, some of it quite informal. First, Kingfisher conducted a study of the discourse of policy making in New Zealand from 1994 to 1998 (Kingfisher 1999); the results of this work have contributed to our understanding of how the New Zealand government has been working to reconstitute poor single mothers' subjectivity. Second, Goldsmith has carried out small-scale ethnographic research on beneficiaries in New Zealand (Goldsmith 2000) and has a long-standing interest in welfare institutional design and reform (Goldsmith 1997a, 1997b). Third, working as a team, we conducted a series of interviews and focus groups in Hamilton, New Zealand, in early 1999 , 
which were animated by the concerns directly addressed in this article. While small in relation to the data corpus from Kingfisher's U.S. study (which produced over 240 hours of audio tape), the data produced from the five interviews and one focus group we conducted for the purposes of this article are nevertheless robust and oriented specifically to the issue of poor women's subjectivity. The latter data must also be situated in the context of the many informal conversations that both authors have had with numerous women on the DPB, over the last 15 years in Goldsmith's case and over the last 6 years in Kingfisher's. We believe that this informal work compensates for the relatively smaller amount of "official" data on New Zealand. And although the data are not strictly comparable by date, we believe that they speak to ongoing reform trends in both countries.

The women whose talk is analyzed in this article ranged in age from 19 to 48. Each had at least one child; one had four children, and another had five children. They had been on the welfare rolls from between 18 months and 17 years (those who had relationships with the welfare system for long periods in the United States tended to go on and off the rolls, depending on job opportunities and relationships with income-earning men). Two of the U.S. and one of the New Zealand women had never been married; the rest of the New Zealand women had been married once, while the remaining U.S. women had been married from one to three times. Three of the U.S. and one of the New Zealand women were currently cohabiting with men. All of the U.S. women and five of the New Zealand women had participated in paid employment. Finally, all of the U.S. women are Anglo, while of our New Zealand participants mentioned in this article, two are Maori and three Pakeha.

\section{Experiencing the Reforms in the United States}

The poor single mothers in the United States were acutely aware of the dominant ideology of the work ethic and its flip side, the stereotype of laziness. As indicated elsewhere (Kingfisher 1996a, 1996b), the women countered their identification as "lazy welfare queens" by means of a twofold process consisting of repeated assertions of allegiance to the work ethic and attributions of laziness to a minority of other recipients. ${ }^{20}$

This assertion of an identity in keeping with dominant views of personhood and enterprising independence, however, was coupled with an equally strong assertion that they were being actively prevented from fulfilling the work ethic (and thus acquiring full personhood). Significantly, they claimed that the site of such prevention did not reside in themselves, as dominant views of the "lazy poor" claim, but in the welfare system and, more broadly, in society at large.

Thus, while accepting the work ethic as a positive value, and accommodating dominant definitions of work as paid work, the women argued that their individual efforts were not sufficient and that therefore they could not be blamed as individuals. As Susan Harrison put it, bluntly:

I worked my ass off, that's why I got a bad back now at the age of 33, because I have worked so hard thinking that was the way you had to go, you know, to make something of yourself, which is a bum-fuck lie. [LIFE, 8/19/90]

The reason the idea of working hard to "make something of yourself" is a "bum-fuck lie" is that neither the world of work nor the welfare system is set up to meet the needs of single working mothers. This view was perhaps most eloquently expressed by Louise Black, who responded to the suggestion by a welfare rights participant that women who bear more than three children while on the welfare rolls be forced to have tubal ligations by arguing that the problem is not women's bodies but divorce, unemployment, and the wage gap. Louise made this argument in the context of an MWRO meeting, the relevant excerpt of which follows. Participants in the following transcript segment from the meeting included Nora Philips (N), Susan Harrison (S), and Louise (L) (note that capital letters indicate emphatic delivery, parentheses bind uncertain or undecipherable words, and double parentheses bind nonverbal vocalizations/activities or transcriber's comments).

\section{Transcript \#1: "What do ya wanna be when you grow up?"}

$1 \mathrm{Li}$ MOST of the time we're on welfare and MOST of the peo-

2 ple who are on welfare are out there WORKING most of

3 the time, NObody's gonna tell me I can't have any kids

4 because I happen to be on welfare for a little bit of time 5 N: no

6 L: Nobody's gonna tell me because I happen to have a

7 divorce that THEY'RE GONNA DO SOMETHING TO

8 MY BODY SO I CAN'T HAVE BABIES, uh uh, uh uh,

9 that's CRAZY, you know?

$10 \mathrm{~N}$ : I mean, that's what they want with, that's what they think

11 they should do

$12 \mathrm{~L}$. SURE, they think somehow, they... spread this stuff that

13 you know people are born-

$14 \mathrm{~N}$ : we're no good

$15 \mathrm{~L} i$ and they say, they go to school and they say "what do ya

16 wanna be when you grow up," say "I wanna be on

17 WELFARE, have FOUR HUNDRED KIDS" you know?

$18 \mathrm{~S}$ : that's it, that's it, yeah

$19 \mathrm{Li}$ and, so they say "well, there's this whole GROUP of

20 people that wanna just $B E$ on welfare and have babies and

21 we have to STOP them before they take over the

22 WORLD," THAT"s just a BUNCH a SHIT

$23 \mathrm{~S}$ : yeah, but you know what?

$24 \mathrm{~L}$ i people are on ... welfare because there AINT' no jobs,

25 because they're gettin... DIVORCED and because they pay

26 women 50 cents on a DOLLAR for what they men, and

27 we're the ones that always have the babies

[MWRO, 4/4/90, side 1, segment 20.41-21.34] 
Louise's claim, is, first of all, that most people on welfare "are out there WORKING" most of the time that they are on welfare (lines 1-2). The reason that people are on welfare therefore has nothing to do with their own motivation to work. That is not at issue. What is at issue is the context within which they are working, and that context is characterized by high rates of unemployment (line 24) and by low levels of pay for women (lines 25-26), who are, after all, "the ones that always have the babies" (line 27) and therefore the ones who usually end up on the welfare rolls after they have been divorced. In Louise's construction, the typical welfare mother (of which she is representative) is someone who was married - and therefore had her children legitimately - and who then got in financial trouble because she got divorced and either could not find a job at all or found only jobs that paid too little to meet the basic subsistence needs of her family. In this formulation, what needs controlling is the economy, not women's bodies.

As the following transcript segment indicates, the women's efforts to repair their "spoiled identities" (Goffman 1963) revolved around this constellation of expressions of the aspiration to paid work, claims that paid work did not allow them to fulfill their family responsibilities, and assertions of the importance of motherhood. The exchange took place in the context of a LIFE meeting; participants included Susan Harrison (S), Dana Kingston (D), and Susan's boyfriend Tom Harris (T):

\section{Transcript \#2: "circumstances HAPPEN"}

1 S: I had my kids before I ever SEEN WELfare, you know

2 T: that's right

3 S: circumstances HAPPEN

4 D: I was married when I had my kids... I never THOUGHT Id

5 be on welfare

6 S: so was I ((laughs)) you know, but that's the way they

7 THINK, they think if you have kids, you're ... like they are,

8 you goin' to school 'til you're 28 or whatever,

9 you got your job you got your career, and that's the way it

10 SHOULD be, but that's not the way it is

11 D: no () work very well, I didn't (go to work) not until my

12 kids were in school

$13 \mathrm{~S}:$ I, I wanted a career, but my situation was a little bit

14 different

$15 \mathrm{D}$ : I did TOO, but ... not 'til my kids were in SCHOOL, I mean

16 'cause otherwise-

17 S: WELL WHY SHOULD A MOTHER HAVE TO GO OUT

18 AND WORK ANYWAY? WHY SHOULD SHE, when,

19 the first five years is so important to 'em, and I mean they

20 got peoples PROFESSORS, or DOCTORS in their FIELD

21 sayin' it, you know? A CHILD needs to be lo- with their

22 mother for the first years, or fathers, whichever the case

23 may be, whichever the BEST parent is, you know

[LIFE, 8/19/90, tape 1 , side B, segment 32.48-33.52]

As Louise Black claimed in U.S. transcript \#1 with regard to most recipients, Susan and Dana were mothers-and married-before they became welfare mothers (lines 1 and 4). In addition, both women had wanted "careers" (lines 13-15). But-and this is the key-they were not interested in engaging in paid work until their children were of school age. Dana makes this point twice (at lines 11-12 and 15), in response to which Susan emphatically declares "WELL WHY SHOULD A MOTHER HAVE TO GO OUT AND WORK ANYWAY? WHY SHOULD SHE, when, the first five years is so important to 'em" (lines 17-19). What is being produced in this exchange is an assertion of mothering as women's primary role. And Susan and Dana are not the only people who believe this - the experts believe it too (lines 20-21). Thus the women's assertion of belief in the work ethic is modified to claim that the pursuit of paid work must be delayed until children reach a certain age, in this case, school age. This desire to delay engaging in paid work until children were in school was further justified by the fact that the employment the women had access to was poorly paid. If they could be in paid labor and make ends meet, they would be happy to do so, but if not, they would rather spend the time with their children. Again, while this line of thought gives some indication of agreement with the work ethic, it comes with the stipulation that pay levels be sufficient to meet one's basic subsistence needs, which in the women's case meant their children's needs as well as their own. If the women were to be "workers," then, they were workers of a particular sort, that is, tied into family units. As such, they required a version of the "family wage," which would provide both recognition and material support for their roles as primary breadwinners. ${ }^{21}$

Because it was so difficult to be a single working mother, the women sometimes contemplated life without their children. It was never a pleasant contemplation, however, even under the best of circumstances. And the result of such contemplations always led back to reflection on the deficiencies of the social-economic system, in particular, those related to the roles and responsibilities of fathers, as the next transcript excerpt indicates:

\section{Transcript \#3: "why are they getting AWAY with it?"}

If women were "natural" caretakers of babies and children, then men were "natural" providers of financial support. Thus, in addition to arguing against workfare and in favor of being able to fulfill their roles as primary caretakers, the women asserted that fathers, too, should be held responsible for children. This view was expressed in the following exchange, in which Katie Devon (K), Susan Harrison (S), and myself $(C)$ responded to a television program that had outlined punitive welfare policies directed at single mothers:

$1 \mathrm{~K}$ : that REALLY bothers me, you go ... to the STORE with

2 FOOD stamps, and you get some MAN standing behind

3 you looking at you like you're trash

4 S: mm huh 
$5 \mathrm{~K}$ : you know, I mean I've had people even make

6 COMMENTS, you know, I've turned around and said, you

7 know, to some guy, "how many babies aren't YOU paying

8 for right now?"

9 C: oohhhh

$10 \mathrm{~K}$ : you know, and he just SHUT UP

$11 \mathrm{~S}$ : that's it

$12 \mathrm{~K}$ : you know, just like ((laughs))

$13 \mathrm{~S}$ : but I think, you know, if they're gonna make us WOMEN

14 do it, they better damn site put the damn cuffs on those

15 guys and make them do the same thing, because this is

16 ridiculous, why make the women and the children suffer

17 and the man's just slapped on the HAND?

$18 \mathrm{~K}$ : if you get ( ) if we could GET child support from our

19 spouses and the fathers of our children, then we could make

20 it, that's what I see

$21 \mathrm{~S}$ : yeah, that IS true

$22 \mathrm{~K}$ : if I could get help

$23 \mathrm{~S}$ : BUT, the FATHERS is having the same problems as WE

24 are because there's no jobs out there, they don't have the

25 training for the jobs

$26 \mathrm{~K}$. right

$27 \mathrm{~S}$ : but why are they getting AWAY with it, why not stick their

28 asses in the same school they got us goin' to, it takes two

29 people to make a baby, it's gonna take two people to pull

30 that baby through, not just one

[MWRO 5/20/90, tape 1, side 1, segment 27.33-28.33]

This exchange demonstrates the intersections of the women's resistance to the impositions of the welfare system with both neoliberal discourses of individual responsibility and neoconservative discourses of family values. The women assert fathers' specific responsibilities toward their children (lines 7-8 and 28-30), claiming that if fathers were more responsible, "then we could make it" (lines 18-20). Interestingly, rather than contest the existence of punitive policies, here the women work to extend them to include fathers in their purview (lines 13-15 and 27-28). ${ }^{22}$

In sum, themes in the U.S. data include acquiescence to the idea of the work ethic - and thus claims to full personhood and citizenship - with provisos that recognize women's primary role as caretakers of young children: sufficient support in the form of either wages, child care provisions or contributions from fathers, along with exemption from paid labor until children reach school age. As we demonstrate in the following section, the themes in the New Zealand data are somewhat different, which may reflect both cultural and historical factors.

\section{Experiencing the Reforms in New Zealand}

During the almost 20-year period from 1973, when the DPB was instituted, to 1991, when neoliberal reform began to be put into place, poor single mothers in New Zealand received comparatively generous support from the state. This feeling of being supported as mothers was ech- oed by the women we spoke with, many of whom have experienced the recent shift in the government's definition of women as mothers to an emphasis on all adults as potential able-bodied workers.

This shift in identity has been both recent and radical. Evelyn Haines made this clear when she described the difficulties involved in convincing the welfare system to provide assistance for child care as recently as 1996, just prior to the implementation of the Tax Reduction and Social Policy Bill:

When I came to Kotari ... ((in)) ' 96 ... that ((pursuing a university degree)) was still quite surprising ... ((and the worker said)) "you're going to do all this? . . . wow, you're pushing it. ... Why aren't you just at home and play((ing)) with your child?" because she was only four. And I tried to get them to pay for child care ((so I could attend university and get off the DPB)) ... ((but)) there was very little money for that because it was not in their system that someone would do that. [interview, 2/15/99]

The emphasis at the time was still clearly on mothering. But the 1996 Tax Reduction and Social Policy Bill marked a change in emphasis. As Kathy Fletcher lamented in a focus group discussion, "I think the reality today for . . . solo parents is that the ... focus is not on the children, it's now about becoming ... entrenched in the workforce" (focus group, 2/19/99). This situation, characterized by an emphasis on getting a job, contrasts sharply with Kathy's first experience of being a solo parent on welfare in 1981, when she was "offered a house ... a benefit ... everything I needed to fill the house, whatever I wanted so that I could be a good mother" (Focus group, 2/19/99):

\section{Transcript \#1: "your children don't matter anymore"}

Formerly quite prominent, then-certainly more so than in the United States since at least OBRA in 1981-the emphasis on women as mothers is now no longer in evidence in New Zealand. In the following focus group exchange, three single mothers and two single fathers had been discussing "muck-ups" (i.e., bureaucratic errors for which recipients always paid the price). Tara Taniwha (T) then referred back to a comment that Kathy Fletcher $(\mathrm{K})$ had made earlier, to the effect that women used to be supported as mothers but were no longer. Other participants in the exchange included Sam Hill (S) and Catherine Kingfisher (C):

$1 \mathrm{~T}$ : they, they were there to SUPPORT they were a big help,

2 NOW, THESE days it's like your children don't matter

3 anymore and you've got parents that's got handicapped

4 kids you know THAT doesn't matter anymore

5 S: that's very hard for them to look after those handicapped

6 kids

7 T: and you've got () mothers, and they've got to go, too, nobody really matters anymore that's what the main you know issue is about today, once upon a time you know 
10 you've got to look after your kids, once upon a time

$11 \mathrm{~S}:$ yeah

12 C: $\mathrm{mmm}$

13 T: NOW it's "you better get OUT there"-I dunno, I'm NOT

14 quite too SURE because my kids are grown up but I know

15 for the little ones whether they help you pay I don't know

16 whether they're offering, you go to work and they help you

17 to pay you

$18 \mathrm{~K}$ : child-yeah, partial childcare subsidy

19 T: I'm not too sure

$20 \mathrm{~K}$ : but I think the MAIN issue that that a lot of us are trying to

21 (mainly) concerned with is that on the one hand you've still

22 got ... a real drive for the PLUNKET ... Karitane ((child care

23 organizations)), everything to do with... CARE and then on

24 the OTHER hand, it's real-REALLY confusing because

25 your heart goes with, "ok, I'll give everything up and stay

26 home with my CHILDREN" knowing full well that you've

27 gotta get the ASSISTANCE, because there's also the other

28 half of us that's HUMAN, we WANT things, we want to

29 DO things

[Focus group I, 2/19/99, tape 1, side 1, segment 18.38-20.07]

Tara is clear about the shift in emphasis at Income Support from children and caretaking to paid employment: once, "they were there to SUPPORT they were a big help, NOW, THESE days it's like your children don't matter anymore" (lines 1-3); "NOW," she repeats a moment later, "it's 'you better get OUT there' " (line 13), meaning out in the workforce. Kathy then points to the conflicting messages present in New Zealand society: on the one hand, the goal of various family advocate groups such as Plunketalso funded (partially, and decreasingly so) by the government-which stress "mothercraft" and children's need for positive and stable home environments, and, on the other hand, the temptations of consumer culture, which are underscored by a welfare system that now emphasizes not family life but work life, not taking care of children but taking care of finances, not making a life but making a living:

\section{Transcript \#2: “we've got more suicide rate than} ANYwhere in the world"

The women saw this declining emphasis on mothering as dangerous: families were falling apart because they did not get enough time together and because parents were stretched beyond their limits; children were suffering the consequences of insufficient and inadequate attention and guidance from adults. In the following exchange, Sam Hill (S), a single father, had been describing WINZ's expectations that he participate in full-time training, when Tara Taniwha $(T)$ asserted that children cannot thrive without adult guidance:

1 T: and who's home for the kids-you're too TIRED

2 S: yes

3 T: you're too tired for the kids

4 S: that's, that's the other thing is when you're gonna do your
5 washing and so on

6 T: and... TODAY, in New ZEALAND, we've got more suicide

7 rate, than ANYwhere in the world because of the pressure I

8 mean it's like a mother and father instincts, your-you

9 know your FAMILY comes-your kids if they're small

10 they come first before the job () you've got to feed them,

11 they gotta come first

$12 \mathrm{~S}$ : well the only thing that Social Welfare-

$13 \mathrm{~T}$ : but there's there's nothing now 'cause everyone's so

14 DRAINED, and being a solo PARENT I reckon you know

15 being a solo parent, is, that we're the strong people of

16 ALL

$17 \mathrm{~S}$ : because ()-

$18 \mathrm{C}: \mathrm{mmm}$

$19 \mathrm{~T}$ : we've got to take on KIDS and when our little ones grow

20 up and when they're TEENagers, it's wicked to live with a

21 teenager now

[Focus group I, 2/19/99, tape 1, side 1, segment 8.27-29.04]

The social costs of poorly looked-after children are clear: New Zealand now has a higher youth suicide rate than any other country in the world, "because of the pressure" (line 7). What the welfare system is forgetting in its push for employment is that parenting is work-that it takes a lot of time, effort, and skill —and that its absence will have a negative impact on children. Tara claimed in this regard that single parents, who are responsible for meeting children's financial as well as parenting needs, are "the strong((est)) people of ALL" (lines 15-16). While the U.S. women also made the claim that mothers' employment could have dire consequences for children (transcript \#2; also Kingfisher 1996a), they focused for the most part on the mothering of young children, usually children under the age of five. In New Zealand, in contrast, emphasis was placed on the need for adult guidance until children were safely through their teens. As Tara put it later in the discussion, "I believe at those ages-13, 14, and 15-at those ages I believe they need you the MOST 'cause their body's changing and their mind's changing, everything's changing." Another participant felt that even a 20 year old was "still immature ((because)) they've just got out of their teenage years" (focus group, 2/19/99):

\section{Transcript \#3: "they don't really want to know about it"}

The welfare system's change in focus from women as mothers to women as workers was not only abrupt but also, from the women's perspective, total, such that children were now invisible to the system. Vicky Soul (V), for instance, decided to take university courses as opposed to seeking employment while on the DPB so that she could have the flexibility to be with her children when they needed her. As the following interview excerpt indicates, however, WINZ did not consider parenting the priority: 
V: My priority is Jane and Amanda ... my children. I had to be there. ... As a single parent I would not have been able to cope with full-time work because study enabled me to juggle my family. ... They've ((the children)) just benefited from it and developed ... they're very strong little girls now and I'm pleased that I put the time into them.

C: Do you think Income Support shared that view-that, you know, your primary role was to be there for the twins?

V: No, no, not at all, not at all . . . . it's ((parenting)) not acknowledged at all, nothing has ever been discussed about the girls, nothing, they've never ever asked after the health of my children or, you know, ever

C: Really? In the whole six years ((that you've been on the DPB))?

V: No, nothing, nothing whatsoever ... even when I've been in and Ive been financially so stressed, they're not very interested, they don't really care, it's like, so is the rest of the world, so they don't really want to know about it. [interview, 2/17/99]

Tracy Fredericks also claimed "I don't get the feeling ... that they want me to raise my child well" (interview, 2/22/99), and a number of women pointed out that welfare offices had no toys to keep children occupied during the usually long waits. Rather, WINZ was concerned with "goal-setting meetings" (mentioned by three interviewees) and with recipients' efforts to "better themselves," the latter having to do with work-readiness training, not mothering. As Diane Bould put it, "Obviously just being a mother wasn't enough as far as they were concerned" (interview, 2/21/99).

There thus seemed to be a major disjuncture between women's views of their role and the welfare system's priorities. One woman did, however, worry about role models for children, thus expressing some support of the work ethic:

I agree basically really your kids come first, they're important, but for me it's a bit different in that I'm mum, dad, grandparents, everybody to my children and so I'm constantly aware of what to provide all of these role models and for me it's very important that I show my children you can do that and be self-sufficient, you don't have to be dependent on the state. [Sandra Temple, focus group, 2/19/99]

The women's most common response to the admonition to engage in paid work, however, was hopelessness - a sense that they were being asked to do the impossible:

I'm a fighter, but I'll tell you what, I've just ... felt like lying down and dying and I've seen other people lie down and die and it's heartbreaking to see your own, to see people that, you know, that really have been onto it ... just curl up and die, you know, and yet for what, over money, you know, and we're a country that we know we've been really self-sufficient, we're all strong people, we're good people. I know that most of us are not perfect, but what the hell do you do to deserve to be denied the very things that you were brought up to believe in, you know, like our belief that was instilled in us by our parents, and we're not all bums and losers like we've been made out to be. [Kathy Fletcher, focus group, 2/19/99]

In sum, our New Zealand respondents circled around four main themes: a sense of nostalgia for a recently lost past, an increasing disjuncture between women's priorities and those of the welfare system, an emphasis on women as mothers, and an assertion that children needed parenting until they reached adulthood.

\section{Transitions}

Data in both countries indicate that the concept of "transition" is both immensely useful and problematic. To complicate matters, several transitions are indexed in the data, not all of which we have the time or space to illustrate in detail in this article. Here we focus on transitions that illustrate general points of similarity and difference between the two countries.

One notion of transition that was evident in the discourse of respondents in both countries concerned transitions in motherhood. In neoliberal discourse, as in certain kinds of liberal feminism, it is as though motherhood has become a transitional phase between periods of education/training and "real" work (i.e., paid employment). It is more than the fact that the period of time allocated in women's lives to childbearing and child rearing has shrunk or that these activities have become increasingly optional-though such changes are real. Rather, the status of motherhood, which, in the welfarism based on "full employment" of male breadwinners in single-income nuclear families, had been an identity defining most women from marriage until old age, is no longer the uninterrupted, longterm, and primary role it once was assumed to be.

One sign of the transition to generic worker evident in both contexts is that the role which female DPB and AFDC recipients were explicitly paid to carry out-motheringremains overwhelmingly tacit in the women's accounts of bureaucratic advice and policing. References to mothering and welfare in our transcripts were typically situated in terms of complaints of how unsupportive the agencies of state are in their proper conduct and of how insignificant the place of children is in the assessment of need (see U.S. transcript \#3 and New Zealand transcripts \#1 and \#3). In the New Zealand case in particular, this represents a marked change from the intrusively child-oriented policies of previous New Zealand welfare regimes (e.g., the ubiquitous Plunket Society and the Maori district nurse scheme, which were integral to the first phases of the "cradle-tograve" welfare system). ${ }^{23}$

In modern nation-states, motherhood has generally been portrayed as a natural "calling," as opposed to a job. Now it is supposed to be not only a vocation that women can undertake without training or direct state support but one that has to compete with training for the "real work" of paid labor, at a time arbitrarily chosen by the state, 
which currently ranges from when children reach 14 in New Zealand to a variety of much younger ages in the United States. This transition has been more abrupt and recent, and therefore more jarring, in New Zealand, which may explain the New Zealand women's greater rejection of the work ethic and greater nostalgia for the past. Thus many of our New Zealand respondents harked back to an indeterminate and quasi-mythical past in which the welfare state provided the kind of support and nurturance compatible with New Zealanders' self-image of egalitarianism and justice. This rhetoric of nostalgia is best summed up in Tara Taniwha's reference to "once upon a time" (see New Zealand transcript \#1, lines 9-10). ${ }^{24}$ In general, however, our interview data suggest that many New Zealand and U.S. single mothers resent this construction of them as workers or workers-in-waiting (see U.S. transcript \#2 and New Zealand transcript \#2). And yet even those who are most critical of this construction also engage in it, perhaps because they have little choice. They strive to (re-)create themselves as "flexible workers" through training and education.

In addition to the difference in relation to levels of nostalgia, the New Zealand and U.S. women also differed in terms of who they felt was obliged to support them in their roles as mothers. As U.S. transcript \#3 indicates, the U.S. women were oriented toward men and the nuclear family. They felt clearly that welfare reform should target fathers as well as mothers, and they valorized the nuclear family (a valorization shared by PRWORA). In contrast, the New Zealand women were overwhelmingly oriented to the state for the support of mothering in cases of family breakdown. Their (financial) lament was not so much for the loss of husbands' support but for the loss of what they referred to as their "entitlements" from the state; and they complained that representatives of the state now "all treat you as if you're coming in and trying to get them in and it's their money and they're going to hang onto it" (focus group, $2 / 19 / 99$ ). This is not to claim that familial relationships were unimportant to the New Zealand women; rather, it is to say that they had grown up with a cradle-to-grave welfarism that had suddenly disappeared.

\section{Conclusions: Where to Next?}

Our respondents did not appear to routinely monitor the broader changes underpinning the neoliberal agenda in welfare "reform." They were generally in agreement that changes had occurred, usually for the worse (thus the rhetoric of nostalgia) but not unequivocally so. Some were in fact quite happy about a few of these changes (e.g., the encouragement to educate themselves for future employment, the transition from physically queuing in buildings to temporally queuing on telephones, etc.). But, on the whole, policy changes seemed irrelevant except insofar as they had a direct impact on the women we listened to.
Their horizons were, understandably, often focused on questions of survival, such as, Has my benefit been raised, lowered, or kept at the same rate since the last payment? Will it be paid at all, and if not, whose fault will that be? Whom will I have to deal with if there is a problem? What new rule change is in operation this week but may be superceded or ignored by the next? In both countries, welfare for poor single mothers has always been relatively grudging, punitive, and intrusive. The boundaries between deserving and undeserving may be changed by cultural pressure and policy fiat but the fact of the boundary itself remains, and it is one which women interacting with the system must learn to negotiate flexibly.

Aside from their need to deal with bureaucracies on a day-to-day basis and to focus on the here and now for their children, there is another reason why the accounts of most beneficiaries are more contingent and complex than the metanarrative(s) of comparative welfare policy researchers: the women concerned have qualified for the DPB and AFDC at different times in their histories and for varied lengths of time over those histories. For some of them, even if conditions on welfare may be said to have gotten "objectively" worse (reduced benefits, tighter eligibility restrictions), their ability to deal with the system may have improved. One of our New Zealand respondents, Evelyn Haines, for instance, described herself as being in a state of shock during her first year on the DPB, when conditions were relatively benign. Over the next four years, however, while conditions on the DPB have steadily worsened, she adapted to become a skilled and resourceful manipulator of the system. Women in the United States made similar points about learning the ropes-not only through their own time and experiences on welfare but also from those of other recipients (Kingfisher 1996a, 1996b).

In short, these women engage at a distance from and at a tangent to the historical processes of globalization that provide a context for welfare reform. It is important in our attempts to understand their experiences, therefore, that we do not mirror the arrogance of governmental welfare providers, in general, and neoliberal reformers, in particular. Even commentators on different sides of the ideological struggle over the future of welfare have a tendency to share certain assumptions, such as the view that policy changes flow from the rich, powerful, and privileged to those less fortunate and that long-term historical changes map evenly onto the lives of individuals. Our research and analysis suggest that we need to be wary of this curious permutation of "trickle-down" theory. The triumph of neoliberalism may be short-lived. The U.S. women were not ready to completely sacrifice themselves to the god of individual responsibility. Nor has the ethos of egalitarianism been totally extinguished in New Zealand. Indeed, our data show that it occupies a cultural space from which it may yet reemerge as a resource for political mobilization. The 
election in late 1999 of a leftward-leaning Labour/Alliance coalition government provides one manifestation of this.

Finally, while globalization may have eased the spread of neoliberal agendas by undermining the sovereignty of nation-states, by the same token it may have created openings for transnational organizations and international agreements to oppose those agendas. In other words, in a global system, "membership in nation-states ceases to be the only ground for the realization of rights" (Sassen 1996b:33); the global system itself has created "practical and formal openings for the participation of non-State actors" (Sassen 1996b:32). Supra- and transnational organizations, then, along with international legal instruments, may provide arenas for the assertion of social rights being denied at the level of the nation-state. Further development of the argument that social rights are part of the rights of citizenshipand the extension of ideas of citizenship to the international level-will serve to buttress the work of such bodies as the U.N. Committee on Economic, Social, and Cultural Rights (Hunt 1996). In addition, work at the national level, such as the Social Charter drafted by Canada's National AntiPoverty Organization, provides potentially useful models for a variety of global actors (Hunt 1996). Anthropology can contribute to such transnational efforts at intervention by continuing to produce fine-grained and, above all, comparative ethnographic analyses of the articulations of what we currently refer to as the global and the local.

\section{Notes}

Acknowledgments. For their helpful comments on earlier drafts of this article, we would like to thank Norman Buchignani, Edit Horvath-Hallett, Paul Letkmann, Claudia Strauss, the guest editors for this Theme issue, especially Rae Bridgman, and the anonymous reviewers for American Anthropologist. Portions of the first section of this article are from Kingfisher in press.

1. For the most part, we will refer to the country as New Zealand. Our title's use of the combined term Aotearoa/New Zealand may require some explanation then. We have alluded to it for two reasons. First, like many social scientists, we wish to register the Maori renaissance in cultural, constitutional, and political life (notwithstanding the evidence that Maori people have been even more disadvantaged by recent changes in New Zealand political economy than Pakeha, or "whites"). "Aotearoa" is used in most Maori-language discourse as the official name of the country and is recognized as such by the population at large. Second, the forward slash mark in the dual noun "Aotearoa/New Zealand" indexes at a metaphorical level the cultural and economic divide referred to above, a distinction by which the experiences of Maori and Pakeha cannot be simply assimilated to one another. However, while our sample of respondents includes both categories of people, Pakeha are in the great majority, and so, where we cannot be sure that there is a distinctively Maori dimension to the data, the name "New Zealand" alludes to the nation-state in which their responses have been formed. The question of whether welfare reform and state restructuring have taken a distinctive path in reshaping "Aotearoa" remains an open question and one we would like to explore further.

2. As we discuss below in the sections "Neoliberalism" and "From (Gendered) Mother to (Generic) Worker," the notion of able-bodiedness builds on particular constructions of individualism that do not fit the realities of many poor mothers' lives.

3. This is not to claim that all single parents are women or that poor men are not also the targets of reform. Our argument, rather, is that the relationship among gender, parenting, and paid labor is being transformed, with the effect that women's primary responsibility for mothering is erased (yet still assumed) and that they are accordingly expected to be breadwinners. Interestingly, when men are single parents they are awarded considerable (albeit informal) recognition for this role. While full-time working mothers used to be considered unusual, this is no longer the case.

4. One of the enduring paradoxes of New Zealand's "quiet revolution" (James 1986) is that it was largely carried out by an administration supposedly representative of the country's egalitarian and "social democratic" past. It was a Labour government elected in 1984 that set the reform process in place, though many of the changes that have most severely affected poor single women were introduced or intensified by the subsequent National (i.e., "conservative") government elected in 1990 and twice since returned to power.

5. By cultural system, we mean a paradigm for understanding and organizing the world and for informing our practice in it. Neoliberalism is not, then, simply an idea, or a way of thinking about economics but an approach to the world, which includes in its purview not only economics but also politics, not only the public but also the private, not only what kinds of institutions we should have but also what kinds of subjects we should be.

In conceptualizing neoliberalism as a cultural system, we wish to highlight its constructed, contingent, and contradictory nature (see Comaroff and Comaroff 1992). First, neoliberalism is a social construction, insofar as we understand all cultural systems to be fabrications, elements of which have been naturalized. This is not to claim that it is easily deconstructed but, rather, to point out that it is a human invention, the artifact of particular historical and material practices and struggles. The view of a historically situated and unfolding phenomenon leads to our second point, namely, that neoliberalism is contingent. Like any culture, it is never fait accompli but is always in need of accomplishment. Finally, neoliberalism is not a "monolithic apparatus that is completely knowable and in full control of the 'New Right' " (Larner 1999:13); it is not coherent, but contradictory. As Comaroff and Comaroff assert, "culture always contains within it polyvalent, potentially contestable messages, images, and actions" (1992: 27). This potential contestability points, in turn, to the power relationships inherent in culture, power here relating to both "the force of meaning and the meaning of force" (Comaroff and Comaroff 1992:28).

6. Welfare history in the United States, as well as in New Zealand, is considerably more nuanced than that being presented here. Mothers' Pensions, for instance, were complicated 
and uneven across states, as were relief measures in existence prior to Mothers' Pensions. It is not our goal here to provide a detailed historical analysis of the development of the U.S. or New Zealand welfare states. Rather, our aim is to sketch broad brush strokes of historical generalities in order to provide a context for the ethnographic data that follow. Those interested in more detailed historical analyses of the U.S. and New Zealand welfare states could consult, for example, Boston et al. 1999; Koven and Michael 1990; Skocpol 1991; and Rudd and Roper 1997.

7. New Zealand has a three-tiered system, consisting of (1) benefits for "categories of people who are likely to be in need-the unemployed, the sick, invalids, widows and sole parents" (Stephens 1999:240); (2) supplementary assistance, "which recognises that different people have different unavoidable expenditures" (Stephens 1999) (e.g., accommodation supplement and child care subsidy); and (3) "safety net" assistance for emergency and special needs (Stephens 1999). Notably, the DPB is on the same tier as unemployment and old-age pensions. In addition, all programs are funded through general tax revenues. In contrast, the United States has a twotiered system divided between (1) social assistance (e.g., unemployment and social security) and (2) financial assistance (e.g., "welfare"/AFDC). Social assistance, funded through the contributions of paid workers, is the less stigmatized of the two tiers, while AFDC, falling in the second tier, has been highly stigmatized, at least in part because it has been "noncontributory," that is, funded through general revenues (i.e., at taxpayers' expense).

8. Esping-Andersen (1996:10) refers to three "distinct welfare state responses to economic and social change": the Scandinavian route, consisting of expansion of welfare state employment; the labor reduction route, followed in continental Europe; and the neoliberal route, followed by the AngloSaxon countries, including the United States and New Zealand.

9. We use the term workfare to refer to a constellation of work-related activities that may include education/training, active employment searches, and volunteer work, as well as paid employment.

10. The 1981 Omnibus Budget Reconciliation Act (OBRA) did two things to AFDC: it reduced federal outlays to AFDC by 14.3 percent, and it tightened eligibility requirements. In addition, and building on the 1967 Work Incentive Program, greater emphasis was placed on the idea of workfare, insofar as states were now both permitted and encouraged to implement state-administered work programs. These changes were designed to contribute to then President Reagan's goals of smaller government, increased productivity (insofar as welfare recipients were not considered productive), and greater labor force flexibility (by getting recipients to respond to business needs) (O'Connor 1998). In terms of the latter two goals, OBRA marked the beginning of a shift in ideas concerning women's roles as mothers versus workers (Abramovitz 1988).

11. Three aspects of the Family Support Act of 1988 (FSA) are noteworthy here. First, by decreasing federal standards and oversight, the act gave states more administrative control over welfare. The act also put into effect parental responsibility measures, the most notable being the garnering of absent fathers' wages. Finally, and most important for our discussion,
FSA extended the workfare option of OBRA by mandating workfare in all states for AFDC recipients with children over particular ages (from one to three, depending on the state) (O’Connor 1998).

12. Three aspects of PRWORA are particularly relevant. First, welfare provision is devolved to the state level, with the federal contribution now being provided in the form of block grants. The outcome of this devolution is a decrease in the standardization of both benefit levels and program requirements. Second, AFDC has been officially eliminated and replaced with Temporary Assistance for Needy Families (TANF). The temporary in TANF indexes the new provision that no one receive welfare benefits for more than five years over the course of their lifetime, the idea being to eliminate cross-generational welfare. Finally, in addition to lifetime limits, and with the help of increased transitional Medicaid and child care benefits, recipients are now required to be involved in workrelated activity by the end of two years on the welfare rolls, on penalty of losing their benefits. The goal of this requirement is to reduce dependency on the welfare system by increasing self-sufficiency.

13. In 1992, maximum AFDC benefits for a family of three ranged from 15 percent to 95 percent of the federal poverty guidelines, depending on the state. For the United States as a whole, median benefits were 39 percent of the poverty line. Nationally, from 1970-92, the median purchasing power of AFDC benefits fell 43 percent. More than half of that reduction occurred between 1980 and 1992 (Center on Budget and Policy Priorities 1992, cited in Axinn and Hirsch 1993).

14. This is not to imply that we consider workfare a positive thing or that New Zealand is in any way "behind the times."

15. What this translated into in terms of the DPB was a reduction of the benefit for a single adult with one child by $\$ 25 /$ week. Adjusted for inflation, benefit levels are now back to what the New Zealand 1972 Royal Commission on Social Security described as subsistence level (Boston et al., eds. 1999:301). In addition, these changes in benefit levels must be situated in the wider context of simultaneous changes to the health system and to housing assistance programs. Taken together, policy changes required that beneficiaries had to pay for more services with fewer resources.

16. There were two pieces of follow-up to the 1996 bill. First, in early 1997, the New Zealand Social Welfare Department sponsored a "Beyond Dependency" conference, in which high-ranking proponents of welfare reform in the United States were featured as key speakers. Particular emphasis was placed on WisconsinWorks, a program widely known for its stringent emphasis on "personal responsibility," "independence," and workfare. The point of the conference was to signal a change in approach to welfare, and it is perhaps not surprising that the conference was held immediately prior to the institution of the changes called for in the 1996 bill. As part of this change in New Zealand's approach to welfare, in February 1998 the government mailed a proposed "Code of Social and Family Responsibility" to every household in the nation. The document outlined a code of individual and family (i.e., private) responsibility for economic, social, and physical well-being, mirroring in many ways the discourse of welfare reform in the United States, from which it got its inspiration. 
17. This second option draws heavily on the idea of contract. The kind of contract at issue here, however, "typically takes the form of the exchange of obedience for protection" (Pateman 1988:31). The relevance of this insight for women's relationship to state provisioning is obvious. In this vein, Brown (1995) underscores the perversity of depending on protection on from that which one must most fear violation-by which she means either individual men, in the case of married women, or "the man in the state," in the case of single mothers. The parties to such a contract are not equal but, in fact, specifically unequal. In this asymmetrical "contract," "if one party is in an inferior position ..., then he or she has no choice but to agree to disadvantageous terms offered by the superior party" (Pateman 1988:57-58). Thus "one party to the contract, who provides protection, has the right to determine how the other party will act to fulfill their side of the exchange" (Pateman 1988:59; see also Fraser and Gordon 1992). The assumption that parties to a contract are what Yeatman (1997) refers to as full contractual persons is thus erroneous. And whereas liberal theory previously awarded "protection" and charity to those deemed to be less than full contractual persons, such "protection" is no longer acceptable under neoliberalism. Indeed, it is deemed to be patronizing and disempowering, contributing to the creation of a particularly insidious form of "unfreedom."

18. See Russell and Edgar 1998 for a discussion of the importance of analyzing the experience of welfare.

19. All organizational, place, and personal names are pseudonyms.

20. This fits with findings from other research in the United States, for example, Seccombe et al. 1998.

21. A key problem for all the U.S. women was that AFDC's child care provisions did not cover their actual child care needs. The combination of low pay (on the non-"family wage" assumption that employees had only themselves to support) with poor AFDC child care provisions placed incredible stress on single mothers who were forced to opt for substandard child care.

Given that the recognition for the women's roles as primary breadwinners was not forthcoming, the women nevertheless struggled to fulfill both roles, asserting their identities as selfless, self-sacrificing, caring mothers who would do anything to meet the needs of their children. As Susan Harrison put it in a discussion of prostitution, "They ((her family)) tell me I ought to be ashamed for what I do and what I've done ((prostitution)) and I look at them and I says 'NO,' you know, 'when I'm ashamed is when my kids ain't got no shoes' " (interview, 4/4/90). This perspective fits with Edin and Lein's (1997) findings on single mothers' efforts to juggle low-paid labor and mothering.

22. According to Goffman (1963:107), stigmatized individuals, many of whom have internalized the societal standards of which they fall short, tend to stratify the groups of which they are members "according to the degree to which their stigma is apparent and obtrusive," allowing them to treat others lower on the hierarchy similarly to how they are treated by society.

23. These two schemes provided on-the-ground parenting support and advice. Plunket nurses, for example, made regular home visits during babies' first six weeks to check feeding habits and weight gain, sleeping patterns, and so on.

24. This sense that things used to be much better is by no means erroneous. There are good grounds to suggest that the period of the 1960s and 1970s, in particular, was marked by welfare provisions of greater generosity and universality than anything achieved before or since (St. John 1998). For poor single mothers in New Zealand, this kind of inclusiveness reached a peak in the few years after the introduction of the DPB in 1973. It was as though the universalism of the welfare state had simply taken its next natural and logical step. For the early beneficiaries of this system and the activists who worked with them to change it, there was a sense of euphoria. By the late 1980 s, however, the DPB itself started to go through a series of transitions that steadily eroded its generosity and ease of access. It became less generous and more targeted. There has also been a major transition in the delivery of benefits, marked by changes in technology and self-governance. Whereas, up until the mid-1990s, all beneficiaries (not just those on, or hoping to get on, the DPB) had been required to report in person to the Department of Social Welfare (or its later incarnations), after that time, beneficiaries were increasingly expected to report over the phone. Face-to-face interaction became less frequent and beneficiaries had to become adept at the rituals of mediated communication that characterize contemporary life ( 800 numbers, touch-tone flowpaths through the bureaucratic maze, and unreturned calls). Those who succeed in this new and detached world do so through a combination of patience, persistence, good phone manners, and verbal skills. The process contributes to their constitution as self-motivated workers, do expectations that they will engage in training and part-time work (or at least attempt to find work, as demonstrated by job-search diaries and rejection letters). In addition to the "goal-setting" meetings described by our respondents (see discussion under New Zealand transcript $\# 3$ ), and according to our respondent Diane Bould, the curriculum vitae (CV) is now becoming a normal part of beneficiaries' presentation of self-a phenomenon that would have been unheard of 20 years ago, when most beneficiaries would not have even heard of a CV. In the New Zealand context, Harris (1998) draws parallels between the CV of curriculum vitae and the $\mathrm{CV}$ of the cardiovascular fitness required of the new responsible citizen-worker. Similar sorts of changes have also been noted by anthropologists (e.g., Martin 1995).

\section{References Cited}

Abramovitz, $\mathrm{M}$.

1988 Regulating the Lives of Women: Social Welfare Policy from Colonial Times to the Present. Boston: South End Press. Appadurai, A.

1996 Modernity at Large: Cultural Dimensions of Globalization. Minneapolis: University of Minnesota Press.

Axinn, J. M., and A. E. Hirsch

1993 Welfare and the "Reform" of Women. Families in Society $74: 563-572$.

Beaglehole, A.

1993 Benefiting Women: Income Support for Women, 1893-1993. Wellington, New Zealand: Social Policy Agency. 
Boston, J., P. Dalziel, and S. St. John

1999 Rebuilding an Effective Welfare State. In Redesigning the Welfare State in New Zealand. J. Boston, P. Dalziel and S. St. John, eds. Pp. 301-316. Auckland: Oxford University Press.

Boston, J., P. Dalziel, and S. St. John, eds.

1999 Redesigning the Welfare State in New Zealand. Auckland: Oxford University Press.

Brodie, J.

1996 Restructuring and the New Citizenship. In Rethinking Restructuring: Gender and Change in Canada. I. Bakker, ed. Pp. 126-140. Toronto: University of Toronto Press.

Brown, $\mathrm{W}$.

1995 States of Injury: Power and Freedom in Late Modernity. Princeton: Princeton University Press.

Cannan, $\mathrm{C}$.

1995 From Dependence to Enterprise? Women and Western Welfare States. In Women and Market Societies: Crisis and Opportunity. B. Einhorn and E. Janes Yeo, eds. Pp. 160-175. Aldershot, UK: Edward Elgar.

Carrithers, M., S. Collins, and S. Lukes, eds.

1985 The Category of the Person: Anthropology, Philosophy, History. Cambridge: Cambridge University Press.

Castles, F. G.

1996 Needs-Based Strategies of Social Protection in Australia and New Zealand. In Welfare States in Transition: National Adaptations in Global Economies. G. Esping-Andersen, ed. Pp. 88-115.London: Sage.

Comaroff, J., and J. Comaroff

1992 Ethnography and the Historical Imagination. Boulder: Westview Press.

Cox, R. H.

1998 The Consequences of Welfare Reform: How Conceptions of Social Rights Are Changing. Journal of Social Policy 27(1):1-16.

Dumont, L.

1980 Homo Hierarchicus: The Caste System and Its Implications. Chicago: University of Chicago Press.

Easton, Brian

1997 The Commercialisation of New Zealand. Auckland: Auckland University Press.

1999 The Whimpering of the State: Policy after MMP. Auckland: Auckland University Press.

Edin, K., and L. Lein

1997 Making Ends Meet: How Single Mothers Survive Welfare and Low-Wage Work. New York: Russell Sage Foundation.

Esping-Andersen, $\mathrm{G}$.

1990 The Three Worlds of Welfare Capitalism. Cambridge: Polity Press.

1996 After the Golden Age? Welfare State Dilemmas in a Global Economy. In Welfare States in Transition: National Adaptations in Global Economies. G. Esping-Andersen, ed. Pp. 1-31.London: Sage.

Fairclough, N.

1991 What Might We Mean by "Enterprise Discourse"? In Enterprise Culture. R. Keat and N. Abercrombie, eds. Pp. 38-57. London: Routledge.
Foucault, M.

1979 Discipline and Punish: The Birth of the Prison. New York: Vintage.

Fraser, $\mathbf{N}$.

1989 Women, Welfare, and the Politics of Need Interpretation. In Unruly Practices: Power, Discourse and Gender in Contemporary Social Theory. Nancy Fraser, ed. Pp. 144-160. Minneapolis: University of Minnesota Press.

Fraser, N., and L. Gordon

1992 Contract versus Charity: Why Is There No Social Citizenship in the United States? Socialist Review 22:45-67.

Geertz, C.

1975 On the Nature of Anthropological Understanding. American Scientist 63:47-53.

Gill, $S$.

1995 Globalisation, Market Civilisation, and Disciplinary Neoliberalism. Millennium 24(3).

Goffman, E.

1963 Stigma: Notes on the Management of Spoiled Identity. Englewood Cliffs, NJ: Prentice-Hall.

Goldsmith, $\mathrm{M}$.

1997a Universal Basic Income and Poverty: Relating AntiPoverty Measures to Basic Income Levels. In Beyond Poverty: Citizenship, Welfare and Well-Being in the 21st Century-Conference Proceedings. M. O'Brien and C. Briar, eds. Pp.52-57. Auckland: Peoples Centre.

1997b Universal Basic Income and the Concept of Citizenship. Social Policy Journal of New Zealand 9:45-54.

2000 Welfare and Freedom in the Twenty-First Century. Pacific World 57(July):33-38.

Harris, $P$.

1998 Donating Labour, Doing CV: Two Forms of Unpaid Work. In Work, Families and the State: Problems and Possibilities for the 21st Century: Conference Proceedings. C. Briar and G. Gill, eds. Pp. 106-110. Palmerston North, New Zealand: Massey University.

Hindess, B.

1997 A Society Governed by Contract? In The New Contractualism? G. Davis, B. Sullivan, and A. Yeatman, eds. Pp. 14-26. Melbourne: Macmillan Education.

Hunt, $P$.

1996 Reclaiming Social Rights: International and Comparative Perspectives. Aldershot, UK: Dartmouth.

James, C.

1986 The Quiet Revolution: Turbulence and Transition in Contemporary New Zealand. Wellington, New Zealand: Allen and Unwin/Port Nicholson Press.

Jesson, B.

1987 Behind the Mirror Glass: The Growth of Wealth and Power in New Zealand in the Eighties. Auckland: Penguin.

Kelsey, J.

1993 Rolling Back the State: Privatisation and Power in Aotearoa/New Zealand. Wellington, New Zealand: Bridget Williams Books.

1997 The New Zealand Experiment: A World Model for Structural Adjustment? Auckland: Auckland University Press/Bridget Williams Books.

1999 Reclaiming the Future: New Zealand and the Global Economy. Wellington, New Zealand: Bridget Williams Books. 
Kingfisher, $\mathbf{C}$.

1996a Women in the American Welfare Trap. Philadelphia: University of Pennsylvania Press.

1996b Women on Welfare: Conversational Sites of Acquiescence and Dissent. Discourse and Society 7(4):531-557.

1998 How Providers Make Policy: An Analysis of Everyday Conversation in a Welfare Office. Journal of Community and Applied Social Psychology 8:1 19-136.

1999 Rhetoric of (Female) Savagery: Welfare Reform in the United States and Aotearoa/New Zealand. National Women's Studies Association Journal 1 1(1):1-20.

2001 Producing Disunity: The Constraints and Incitements of Welfare Work. In New Poverty Studies: The Ethnography of Politics, Policy and Impoverished People in the U.S. J. Goode and J. Maskovsky, eds. New York: New York University Press.

Kingfisher, C., ed.

In press Western Welfare in Decline: Women's Poverty in an Age of Globalization. Philadelphia: University of Pennsylvania Press.

Koven, S., and S. Michael, eds.

1990 Mothers of a New World: Maternalist Politics and the Origins of Welfare States. London: Routledge.

La Fontaine, J. S.

1985 Person and Individual: Some Anthropological Reflections. In The Category of the Person: Anthropology, Philosophy, History. M. Carrithers, S. Collins, and S. Lukes, eds. Pp. 123-140. Cambridge: Cambridge University Press.

Larner, W.

1999 Sociologies of Neo-Liberalism: Theorising the New Zealand Experiment. Sites 36:5-21.

Lukes, $\mathrm{S}$.

1973 Individualism. Oxford: Basil Blackwell.

Martin, E.

1995 Flexible Bodies: Tracking Immunity in American Culture from the Days of Polio to the Age of AIDS. Boston: Beacon.

Mauss, $\mathrm{M}$.

[1938]1985 A Category of the Human Mind: The Notion of Person; The Notion of Self. W. D. Hall, trans. In The Category of the Person: Anthropology, Philosophy, History. M. Carrithers, S. Collins, and S. Lukes, eds. Pp. 1-25. Cambridge: Cambridge University Press.

Mies, $M$.

1986 Patriarchy and Accumulation on a World Scale. London: Zed.

Mishra, R.

1977 Society and Social Policy.London: Macmillan.

Morris, B.

1994 Anthropology of the Self: The Individual in Cultural Perspective. London: Pluto Press.

National Party of New Zealand

1993 Path to 2010: Securing a Future for New Zealanders to Share. Wellington, New Zealand: National Party.

New Zealand Finance and Expenditure Committee

1996 Commentary on the Tax Reduction and Social Policy Bill. Wellington, New Zealand: New Zealand Government.
O'Connor, J.

1998 U.S. Social Welfare Policy: The Reagan Record and Legacy. Journal of Social Policy 27(1):37-61.

Pateman, C.

1988 The Sexual Contract. Stanford: Stanford University Press.

1989 The Patriarchal Welfare State. In The Disorder of Women: Democracy, Feminism and Political Theory. Carole

Pateman, ed. Pp. 179-209. Cambridge: Polity Press.

Ramsay, M.

1997 What's Wrong with Liberalism?: A Radical Critique of Liberal Political Philosophy. Leicester: Leicester University Press.

Richards, R.

1994 Closing the Door to Destitution: The Shaping of the Social Security of the United States and Aotearoa/New Zealand. University Park: Pennsylvania State University Press.

Rose, N.

1989 Governing the Enterprising Self. In The Values of the Enterprise Culture: The Moral Debate. P. Heelas and P. Morris, eds. Pp. 141-164. London: Routledge.

1996 Governing “Advanced” Liberal Democracies. In Foucault and Political Reason: Liberalism, Neo-Liberalism, and Rationalities of Government. A. Barry, T. Osborne, and N. Rose, eds. Pp. 37-64. Chicago: University of Chicago Press.

Rudd, C., and B. Roper, eds.

1997 The Political Economy of New Zealand. Auckland: Oxford University Press.

Russell, A., and I. R. Edgar

1998 Research and Practice in the Anthropology of Welfare. In The Anthropology of Welfare. I. R. Edgar and A. Russell, eds. Pp. 1-15. London: Routledge.

Sainsbury, D.

1996 Gender, Equality and Welfare States. Cambridge: Cambridge University Press.

Sassen, $S$.

1996a Towards a Feminist Analytics of the Global Economy. Indiana Journal of Global Legal Studies 4(1):7-41.

1996b Losing Control?: Sovereignty in an Age of Globalization. New York: Columbia University Press.

Scott, K.

1996 The Dilemma of Liberal Citizenship: Women and Social Assistance Reform in the 1990s. Studies in Political Economy 50:7-36.

Seccombe, K., J. Delores, and K. B. Walters

1998 "They Think You Ain't Much of Nothing": The Social Construction of Welfare Mothers. Journal of Marriage and the Family 60:849-865.

Shaver, $\mathrm{S}$.

1995 Women, Employment and Social Security. In Women in a Restructuring Australia: Work and Welfare. A. Edwards and S. Magarey, eds. Pp. 141-161. Sydney: Allen and Unwin. Skocpol, T.

1991 Protecting Soldiers and Mothers: The Political Origins of Social Policy in the United States. Cambridge, MA: Harvard University Press. 
Starrels, M. E., S. Bould, and L. J. Nicholas

1994 The Feminization of Poverty in the United States: Gender, Race, Ethnicity, and Family Factors. Journal of Family Issues 15(4):590-607.

Stephens, $\mathbf{R}$.

1999 Poverty, Family Finances and Social Security. In Redesigning the Welfare State in New Zealand. J. Boston, P. Dalziel, and S. St. John, eds. Pp. 238-259. Auckland: Oxford University Press.

St. John, S. 1998 Swings and Roundabouts. New Zealand Books 8(5): 4-5.

Susser, I.

1997 The Flexible Woman: Regendering Labor in the Informational Society. Critique of Anthropology 17(4):389-402.

Teeple, G.

1995 Globalization and the Decline of Social Reform. Toronto: Garamond Press.

\section{U.S. Government}

1995 House Proceedings of the Record, March 24. Washington, DC: U.S. Government.

1996 House Proceedings of the Record, July 30. Washington, DC: U.S. Government.

Waldegrave, C., and P. Frater

1996 New Zealand: A Search for a National Poverty Line. In Poverty: A Global Review. Handbook on International Poverty Research. E. Oyen, S. M. Miller, and S. A. Samad, eds. Pp. 160-186. Oslo: Scandinavian University Press; and Paris: UNESCO.

Yeatman, A.

1997 Contract and Personhood. In The New Contractualism? G. Davis, B. Sullivan, and A. Yeatman, eds. Pp. 39-56. Melbourne: Macmillan Education. 